Rev. Int. Contam. Ambie. 32 (4) 425-433, 2016

DOI: 10.20937/RICA.2016.32.04.06

\title{
VERMICOMPOST AS AN ALTERNATIVE OF MANAGEMENT FOR WATER HYACINTH
}

\author{
Dioselina ÁLVAREZ BERNAL ${ }^{1 *}$, Marcos Alfonso LASTIRI HERNÁNDEZ ${ }^{1}$, \\ Héctor René BUELNA OSBEN ${ }^{1}$, Silvia Maribel CONTRERAS RAMOS² and Miguel MORA ${ }^{3}$
}

${ }^{1}$ Centro Interdisciplinario de Investigación para el Desarrollo Integral Regional de Michoacán, Instituto Politécnico Nacional. Justo Sierra 28, Centro, Jiquilpan, Michoacán, México, C.P. 59510

${ }^{2}$ Centro de Investigación y Asistencia en Tecnología y Diseño del Estado de Jalisco A.C. (CIATEJ). Avenida Normalistas 800, Colonia Colinas de la Normal, Guadalajara, Jalisco, México, C.P. 44270

${ }^{3}$ Department of Wildlife and Fisheries Sciences, Texas A\&M University, College Station 77843-2258, Texas, United States

*Autor para correspondencia: dalvarezb@ipn.mx

(Received June 2015; accepted February 2016)

Key words: Eisenia fetida, vermicomposting, Eichhornia crassipes, salinity, metals, organic fertilizer, electrical conductivity

\begin{abstract}
Aquatic weeds, such as Eichhornia crassipes (Mart.) Solms (water hyacinth) can be used as raw material for vermicompost. Vermicompost is the product of microbial decomposition of organic waste through the digestive tracts of earthworms. The aim of this work was to use water hyacinth to obtain stable and mature vermicompost. Three treatments were performed for vermicomposting, treatment one with $100 \%$ of water hyacinth, treatment two with $100 \%$ of cow manure and treatment three with $50 \%$ of water hyacinth and $50 \%$ of cow manure. The earthworm used was Eisenia fetida Savigny. Vermicompost was characterized physically, chemically and microbiologically, and measured by indexes of stability and maturity, as well, metal concentrations were detemined. Germination index was obtained with four different seeds: radish (Raphanus sativus L.), lettuce (Lactuca sativa L.), cucumber (Cucumis spp.) and zucchini (Cucurbita pepo L.). The three different treatments for vermicompost were stable and mature after 110 days with $90 \%$ of E. fetida survival in each treatment. The vermicompost with water hyacinth and water hyacinth plus cow manure had a high $\mathrm{pH}$ and electrical conductivity. Radish had the best performance in germination index and the three vermicompost were rich in metals. We conclude that vermicomposting is suitable for managing water hyacinth because it can produce a stable, mature, and rich in nutrients vermicompost, which is useful as organic fertilizer or soil improver.
\end{abstract}

Palabras clave: Eisenia fetida, vermicompostaje, Eichhornia crassipes, salinidad, metales, fertilizante orgánico, conductividad eléctrica

\section{RESUMEN}

Las malezas acuáticas como Eichhornia crassipes (Mart.) Solms (lirio acuático), pueden ser útiles en la elaboración de vermicompost. El vermicompost es el producto de la 
descomposición de desechos orgánicos por medio de los microorganismos del tracto digestivo de las lombrices. El objetivo de este trabajo fue utilizar el lirio acuático para obtener un vermicompost estable y maduro. Se realizaron tres tratamientos: uno con el $100 \%$ de lirio acuático, el dos con $100 \%$ de estiércol y el tres con $50 \%$ lirio acuático y $50 \%$ de estiércol, la lombriz utilizada fue Eisenia fetida Savigny. Los vermicompost se caracterizaron física, química y microbiológicamente, además se midieron índices de madurez y estabilidad, así como la concentración de metales. El índice de germinación se realizó con cuatro semillas diferentes: rábano (Raphanus sativus L.), lechuga (Lactuca sativa L.), pepino (Cucumis spp.) y calabacita (Cucurbita pepo L.). Los tres tratamientos resultaron ser estables y maduros después de 110 días de vermicompostaje con un índice de supervivencia de E. Fetida de 90 \%, los vermicompost con lirio acuático y lirio acuático más estiércol tuvieron un $\mathrm{pH}$ y una conductividad eléctrica altos. El rábano mostró un buen desempeño en el índice de germinación, los tres vermicompost resultaron ricos en metales. Se concluye que el vermicompostaje es adecuado para el manejo del lirio acuático, debido a que se obtiene un vermicompost estable, maduro y rico en nutrientes, que puede utilizarse como fertilizante orgánico o mejorador de suelos.

\section{INTRODUCTION}

The water hyacinth (WH), Eichhornia crassipes, is an emergent plant of the family Pontederiacea and is considered an invasive plant because of its rapid population growth (Patil 2012). It tolerates intervals of $\mathrm{pH}$, between 6-8, and grows rapidly when nitrogen levels are around $21 \mathrm{mg} / \mathrm{L}$, phosphorus of $62 \mathrm{mg} / \mathrm{L}$, iron of $0.6 \mathrm{mg} / \mathrm{L}$, and at least $5 \mathrm{mg} / \mathrm{L}$ of calcium (Coetzee et al. 2007, Ruíz-Tellez et al. 2008). The $\mathrm{WH}$ is found in bodies of water with high nutrient levels (Malik 2007).

This aquatic weed has caused economic and environmental losses in many countries, because of its rapid growth it can obstruct the access to the pumps used for irrigation, causing water resources depletion, and the spreading of mosquitoes and flies which are vectors of a number of diseases (Ding et al. 2001). There are several ways to handle and control WH including mechanical, biological, and chemical methods. However, it is also used to produce valuable products, such as, biogas, compost and vermicompost (Malik 2007).

Vermicomposting is a biological method where worms such as Eisenia fetida, Eudrilus eugeniae or Lumbricus rubellus (Gajalakshmi et al. 2001, Gupta et al. 2007) are used for transforming organic waste into vermicompost. It has been reported that vermicompost is rich in nutrients and contain enzymes and hormones that stimulate plant growth and help them resist pathogens (Gajalashkmi and Abbasi 2004). However, vermicompost can have a large amount of salts, high electrical conductivity due to the origin from the raw material used, which can be a serious threat for sensible crops (Edwards and Bohlen 1996). The importance of using water hyacinth for vermicomposting is because this method stops its proliferation by eliminating its ability to reproduce (Malik 2007).

Stability and maturity of a vermicompost is important because it indicates when it is ready to be used as organic fertilizer or soil conditioner. One crucial analysis is the germination index that indicates indirectly if the vermicompost contains phytotoxic compounds or a large amount of salts that can damage plants (Barrena et al. 2014, Khan et al. 2014). The aim of this work was using water hyacinth to produce stable and mature vermicompost with Californian red worm in order to give an alternative management of this aquatic weed.

\section{MATERIALS AND METHODS}

\section{Sampling site}

WH was collected from three drains in the irrigation district 024, Ciénega de Chapala, in northeast

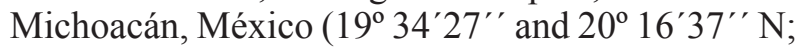
$102^{\circ} 43^{\prime} 16^{\prime \prime}, 102^{\circ} 32^{\prime} 53^{\prime \prime} \mathrm{W}$ ), at an altitude of 1525 masl (INEGI 2014).

The drains in the irrigation district had the following flora: Hydrocotyle vulgaris L., Scirpus spp., Pistia stratiotes L., Lemna minor L. Griff., Phragmites australis (Cav.) Trin. ex Steud., Typha domingensis Pers. and $E$. crassipes, the latter being the most abundant species (PCIMALC 2005).

Samples of WH were washed with potable water to remove sediment particles attached to the roots 
and leaves. The whole plant was cut in segments of 2 to $3 \mathrm{~cm}$. Cattle manure $(\mathrm{CM})$ was collected from a cowshed in Jiquilpan, Michoacán. The main physical and chemical characteristics of WH and CM are shown in Table $\mathbf{I}$.

TABLE I. PHYSICAL AND CHEMICAL CHARACTERISTICS OF RAW MATERIALS FOR VERMICOMPOST

\begin{tabular}{lrcr}
\hline Parameter & \multicolumn{1}{c}{ WH } & \multicolumn{1}{c}{ CM } \\
\hline Moisture (\%) & 92 & \pm 0.3 & $20.4 \pm 1$ \\
Ash $(\%)$ & 79 & \pm 0.5 & $125.7 \pm 1$ \\
$\mathrm{pH}$ & 8.5 & \pm 0.2 & $9.4 \pm 0.2$ \\
Electrical conductivity $(\mathrm{dS} / \mathrm{m})$ & 2.7 & \pm 0.3 & $5.6 \pm 0.2$ \\
Total organic carbon $(\mathrm{g} / \mathrm{kg})$ & 25.5 & \pm 0.6 & $35.9 \pm 11$ \\
Fulvic acid $(\mathrm{g} / \mathrm{kg})$ & $7.8 \pm 0.1$ & $4.7 \pm 0.1$ \\
Humic acid $(\mathrm{g} / \mathrm{kg})$ & $17.7 \pm 0.3$ & $31.2 \pm 0.3$ \\
Total nitrogen $(\mathrm{g} / \mathrm{kg})$ & $0.54 \pm 0.2$ & $7.7 \pm 2$ \\
\hline
\end{tabular}

WH: water hyacinth, CM: cow manure

WH and CM were pre-treated by forming a pile of $50 \mathrm{~cm}$ and covering with a dark plastic bag $(600$ caliber). The pile was watered and turned every other day, during 20 days to eliminate volatile gases potentially toxic to E. fetida earthworms.

\section{Experimental design}

Three beds ( $1 \mathrm{~m}$ wide, $2 \mathrm{~m}$ long and $0.3 \mathrm{~m}$ high) were placed for each treatment, which were 1) $\mathrm{WH}$, 2) $\mathrm{CM}$ and 3) a mixture of $\mathrm{WH}(50 \%)$ and $\mathrm{CM}(50 \%)$ $(\mathrm{WH}+\mathrm{CM})$. Each bed was treated with $1.5 \mathrm{~kg}$ of adult Californian red worms (E. fetida), and then was covered with a shadow mesh to prevent moisture loss and birds eating the worms. The moisture content was maintained and adjusted to $80 \%$ on a daily basis. For survival index of earthworms, a random sample was taken using a framework of $0.5 \mathrm{~m}$ by $0.5 \mathrm{~m}$ each side, placed in the middle of the bed to eliminate the edge effect, at $20 \mathrm{~cm}$ of depth of the bed. Survival was calculated as the ratio between the number of organisms collected at the end of the experiment and the number of initial organisms (Allen 1990). After 110 days earthworms were separated from beds with specific traps. A sample was collected from each bed and then air dried at room temperature in the shade, grounded and stored in a plastic bag for later analysis.

\section{Physical and chemical analysis}

Each sample was analyzed for the following parameters: $\mathrm{pH}$ and electrical conductivity (EC) using distilled water in a 1:10 (w/v), total organic carbon
(Nelson and Sommer 1982), total Kjeldah nitrogen (Bremner and Mulvaney 1982), moisture (Alef and Nannipieri 1995), oxidable organic carbon and $\mathrm{CO}_{2}$ (Sánchez-Monedero et al. 1996), inorganic carbon (Page 1982), cation exchange capacity (Uehara and Gillman 1981), finally, $\mathrm{NH}_{4}{ }^{+}$and $\mathrm{NO}_{3}{ }^{-}$were measured by colorimetric techniques (APHA 1988).

\section{Germination index}

The germination index was measured using seeds of $R$. sativus, Cucumis spp., L. sativa and C. pepo, according to Zucconi et al. (1981).

\section{Microbiological analysis}

Escherichia coli, total and fecal coliforms were determined in vermicompost with USEPA method 1680 (2010), Salmonella spp. with method 1682 (USEPA 1998), and helminth eggs as follows. The samples were mixed with buffered water containing a surfactant $0.1 \%$ (Triton X-100). Afterwards large particles were allowed to precipitate and the supernatant was decanted. The sediment was subjected to a density gradient centrifugation using magnesium sulfate (specific gravity $1.2 \mathrm{~g} \mathrm{~cm}^{-3}$ ). Small particles were removed by a second screening on a small mesh size screen (400 mesh US standard, $38 \mu \mathrm{m}$, stainless steel,) and proteinaceous material by an acid alcohol/ethyl ether extraction. The concentrate was subsequently incubated at $26{ }^{\circ} \mathrm{C}$ for 10 days and microscopically examined for helminth eggs on a Sedgwick-Rafter counting chamber (Hausser Scientific, Horsham, Pa.) (USEPA 2003, Appendix I).

\section{Metal analysis}

A subsample of vermicompost was used to determine metals content $(\mathrm{Ca}, \mathrm{Co}, \mathrm{Cu}, \mathrm{Fe}, \mathrm{Mg}, \mathrm{Mn}$, $\mathrm{Mo}, \mathrm{Se}, \mathrm{Zn}, \mathrm{Si}, \mathrm{B}, \mathrm{Ba}) .0 .3 \mathrm{~g}$ of vermicompost were placed in polytetrafluoroethylene, flame retardant (PTFE-TFM) tubes and were digested in a microwave (Multiwave 3000 Perkin Elmer USA ${ }^{\circledR}$ ) with $1.0 \mathrm{~mL}$ of concentrated hydrochloric acid $(\mathrm{HCl}), 9.0$ $\mathrm{mL}$ of concentrated nitric acid $\left(\mathrm{HNO}_{3}\right)$ and $2.0 \mathrm{~mL}$ of hydrogen peroxide at $30 \%\left(\mathrm{H}_{2} \mathrm{O}_{2}\right)$. The metals were quantified by optical emission spectroscopy inductively coupled plasma (ICP-OES model Optima 4300 DV, PerkinElmer Instruments USA $\left.{ }^{\circledR}\right)$.

\section{Statistical analysis}

An analysis of variance was conducted along with a Tukey test to determine significant differences between treatments using the statistical package SAS $9.1^{\circledR}$ (2004). The significance level was set at $\mathrm{P} \leq 0.05$. 
TABLE II. MATURITY AND STABILITY INDEXES FOR VERMICOMPOSTS OBTAINED WITH VERMICOMPOSTING PROCESS

\begin{tabular}{|c|c|c|c|c|c|}
\hline Parameter & WH & $\mathrm{CM}$ & $\mathrm{WH}+\mathrm{CM}$ & SMD & $\begin{array}{l}\text { Maturity and } \\
\text { stability index }\end{array}$ \\
\hline $\mathrm{pH}$ & 8.5 & 8.0 & 9.4 & 3.9 & - \\
\hline $\mathrm{EC}$ & 3.34 & 2.10 & 4.01 & 0.35 & - \\
\hline Bulk density (g/ ml) & 0.5 & 0.6 & 0.6 & 0.1 & - \\
\hline $\mathrm{N}-\mathrm{NH}_{4}^{+}(\mathrm{mg} / \mathrm{kg})$ & 165.7 & 149.3 & 135.3 & 12.7 & $<400^{1}$ \\
\hline $\mathrm{N}-\mathrm{NO}_{2}^{-}(\mathrm{mg} / \mathrm{kg})$ & 1.5 & 1.5 & 8.02 & 5.23 & $<5^{2}$ \\
\hline $\mathrm{N}-\mathrm{NO}_{3}{ }^{-}(\mathrm{mg} / \mathrm{kg})$ & 88.39 & 128.33 & 94.04 & 30.11 & $<500^{3}$ \\
\hline $\mathrm{NH}_{4} / \mathrm{NO}_{3}$ & 1.8 & 1.16 & 1.43 & 1.1 & $<3^{3}$ \\
\hline $\mathrm{HA} / \mathrm{FA}$ & 2.6 & 0.4 & 3.8 & 2.0 & $>1.9^{5}$ \\
\hline $\mathrm{FA}(\mathrm{g} / \mathrm{kg})$ & 7.8 & 19.8 & 4.7 & 10.5 & $\leq 12.5^{1}$ \\
\hline CEXC (g/kg) & 3.32 & 6.9 & 6.74 & 3.05 & $\leq 60^{1}$ \\
\hline TOC $(\mathrm{g} / \mathrm{kg})$ & 255 & 282 & 224 & 21.1 & $>200^{6}$ \\
\hline $\mathrm{CO}_{2}(\mathrm{mg} / \mathrm{kg} /$ day $)$ & 30.6 & 48 & 49.04 & 15.8 & $\leq 120^{4}$ \\
\hline
\end{tabular}

${ }^{1}$ Bernal et al. (1998), ${ }^{2}$ ASCP (2001), ${ }^{3}$ TMECC (2010), ${ }^{4}$ Hue and Liu (1995),

${ }^{5}$ Iglesias-Jiménez and Pérez-García (1992), ${ }^{6}$ Lasaridi et al. (2006)

$\mathrm{WH}$ : water hyacinth, $\mathrm{CM}$ : cow manure, $\mathrm{WH}+\mathrm{CM}$ : water hyacinth plus cow manure, SMD: Significance minimal difference $(p \leq 0.05)$

HA/FA: humic acid-fulvic acid ratio, FA: fulvic acid, CEXC: cation exchange capacity, TOC: total organic carbon

\section{RESULTS AND DISCUSSION}

A stable and mature vermicompost was obtained after 110 days and their chemical and physical properties are shown in Table II. Gupta et al. (2007) reported 147 days to obtain stable and mature vermicompost, while Gajalakshmi et al. (2001) reported six months. In our study, the shorter process time was due to the large amount of earthworms added to each bed. In each bed the survival index was $90 \% \pm 2$, indicating that the earthworms adapted to the materials used and that the $\mathrm{WH}$ from drainages did not contain compounds that interfered with their development. This is in contrast with Singh and Kalamdhad (2013) who found a decrease in earthworm survival, being necessary to use a mixture of $25 \% \mathrm{WH}$ and $75 \%$ cow dung. An increase in the percentage of WH in the mixture resulted in an increase in mortality of these earthworms (Galakshmi et al. 2001, Gupta 2007, Zirbes et al. 2011). Pre-compost is necessary to avoid earthworm mortality (Mupondi et al. 2011).

The $\mathrm{pH}$ was slightly saline in the three vermicomposts. CM and WH had a $\mathrm{pH}$ of 8.5 and 9.4 respectively, and EC ranging from 3.3 to $4.01 \mathrm{dS} / \mathrm{m}$, indicating important presence of salts which may have little impact on salt tolerant crops (Table II). These results of EC were similar to those reported by Cardoso and Ramírez (2001) with an EC of $4 \mathrm{mmhos} / \mathrm{cm}$ and a $\mathrm{pH}$ value of 7.2. Vermicompost produced with $\mathrm{WH}$ and biosolids is alkaline because the calciferous glands add calcium (Bollo 1999). However, Gupta et al. (2007) obtained a $\mathrm{pH}$ value of 7 after 147 days with vermicompost of bovine manure and $\mathrm{WH}$.

WH has been considered a natural kidney for disturbed waters. It has been used as a biofilter of wastewater rich in organic and inorganic nutrients, as well as water contaminated with toxic metals and persistent organic compounds (Malik 2007). WH also takes salts from drainage water (Zhou et al. 2007, Singh and Kalamdhad 2013). Waters from the drainage system of Ciénega de Chapala are brackish (Silva-García et al. 2006), and CM has a large amount of salts as well (EC $5.5 \mathrm{dS} / \mathrm{m}$ ), which explains the high values of $\mathrm{pH}$ and $\mathrm{EC}$ found in the vermicompost in this study.

The organic matter content and cation exchange capacity of the three vermicomposts were high (Table II), indicating that they are rich in nutrients and therefore suitable as organic amendment. It is known that vermicomposting of solid waste results in nutrient rich humus, produced by microorganisms in the digestive system of earthworms (Gajalashkmi and Abbasi 2004).

Vermicompost stability is related with the decomposition of organic matter (Bustamante et al. 2008), measured by mineralization of carbon and nitrogen $\left(\mathrm{CO}_{2}\right.$ and $\left.\mathrm{NH}_{4}^{+}\right)$. The values of $\mathrm{CO}_{2}$ and $\mathrm{NH}_{4}^{+}$obtained indicated stability despite significant differences between treatments (Table II). The maturity indicates that vermicompost can be used 


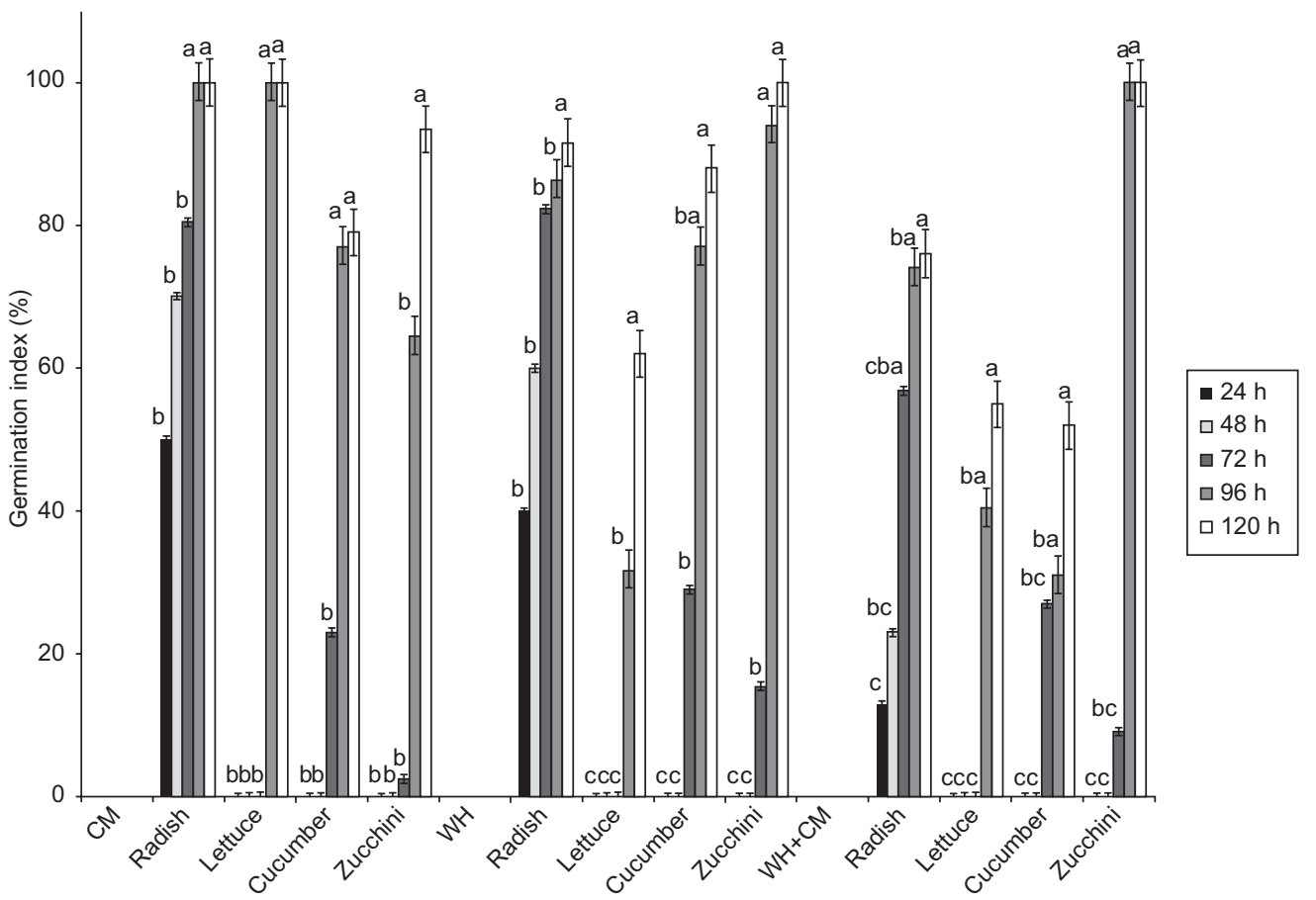

Fig. 1. Germination index of different seeds with extracts of vermicompost $\mathrm{CM}$ : cow manure, $\mathrm{WH}$ : water hyacinth, $\mathrm{WH}+\mathrm{CM}$ : water hyacinth plus cow manure. Bars with the same letter mean there are no significant differences $(\mathrm{p} \leq 0.05)$

as organic fertilizer to be microbiologically stable. The parameters that indicate maturity in compost are oxidizable organic carbon, $\mathrm{C}: \mathrm{N}$ ratio and germination index (Sánchez-Monedero et al. 2001). For the oxidizable organic carbon and $\mathrm{C}: \mathrm{N}$ ratio, there were significant differences between samples (Table II), these results indicate stability and maturity in the three treatments.

Germination index (GI) is one of the most important parameters for stability. The sensitivity of seeds to the phytotoxic compounds and salts was varied and the best response was the radish with germination at 24 $h$. In contrast, the other seeds had an adaptation phase and there was no germination in the first $48 \mathrm{~h}$ until the $72 \mathrm{~h}$ were reached. Vermicompost $\mathrm{WH}+\mathrm{CM}$, had lower rates of germination for all seeds, due to its high conductivity (Fig. 1). Zirbes et al. (2011) suspects that the phytotoxic compounds from $\mathrm{WH}$ are responsible for the low percentage in germination index.

The lettuce seeds are more sensitive to salts and phytotoxic compounds. In all the vermicompost the germination of these seeds was recorded until 96 h. Germination in vermicompost WH was $70 \%$, in $\mathrm{WH}+\mathrm{CM}$ was $80 \%$ after $120 \mathrm{~h}$, and $100 \%$ in CM. The above indicates that despite having different degrees of maturity, and no phytotoxic compounds, salts affect germination stage.
Vermicompost with WH had a low rate of GI with seeds of cucumber and lettuce compared with seeds of radish (Fig. 1). These results coincide with those from Zirbes et al. (2011), who found a low percentage of GI with vermicompost of WH. In contrast, zucchini seeds have one hundred \% of GI despite the high EC of the WH vermicompost.

Mixed vermicompost $\mathrm{WH}+\mathrm{CM}$ had a lower GI in most seeds compared with other treatments, likely because of the salt excess, and EC of $4.01 \mathrm{dS} / \mathrm{m}$. Patidar et al. (2013) found a $60 \%$ of GI for radish with a mixed vermicompost $(\mathrm{WH}+\mathrm{CM})$.

Metal concentrations in three vermicompost are shown in Table III. There were no significant differences among treatments, and most of the metals were in great concentrations (i.e. Ca $15028 \mathrm{mg} / \mathrm{kg}$ ), except for $\mathrm{B}, \mathrm{Ba}$, Se and Mo. There is evidence that metals accumulate in WH. Singh and Kalamdhad (2013) found similar concentrations of $\mathrm{Zn}, \mathrm{Mn}, \mathrm{Cu}$ and Fe after 45 days of vermicomposting. Nevertheless, a high $\mathrm{pH}$ reduce bioavalibility of these metals (Ingelmo et al. 2012). The concentrations of $\mathrm{Co}$ and $\mathrm{Cu}$ in the three treatments were below the upper limits reported by the European Comission (2014) and WRAP (2014). Zinc was found within the upper limits of US Composting Council (TMECC 2010), but was higher for European Comission and WRAP. It is important to 
TABLE III. METALS IN VERMICOMPOST

\begin{tabular}{lccccc}
\hline Metal & $\begin{array}{c}\mathrm{CM} \\
(\mathrm{mg} / \mathrm{kg})\end{array}$ & $\begin{array}{c}\mathrm{WH} \\
(\mathrm{mg} / \mathrm{kg})\end{array}$ & $\begin{array}{c}\text { WH+CM } \\
(\mathrm{mg} / \mathrm{kg})\end{array}$ & SMD & $\begin{array}{c}\text { Upper } \\
\text { limit }\end{array}$ \\
\hline $\mathrm{Ca}$ & 15028 & 17161 & 12453 & 1508 & - \\
$\mathrm{Co}$ & 28.863 & 31.777 & 27.640 & 9.14 & $\begin{array}{c}70-600^{\mathrm{a}} \\
\end{array}$ \\
& 46.197 & 47.807 & 47.057 & 16.2 & $70^{\mathrm{b}}$ \\
$\mathrm{Cu}$ & 9353 & 12875 & 8163 & 1025.8 & - \\
$\mathrm{Fe}$ & 5361.4 & 6644.2 & 6107.5 & 1439.8 & - \\
$\mathrm{Mg}$ & 392.9 & 550 & 222.7 & 335.4 & - \\
$\mathrm{Mn}$ & 27.72 & 29.99 & 28.91 & 2.81 & - \\
$\mathrm{Mo}$ & 18.11 & 13.58 & 20.94 & 12.9 & - \\
$\mathrm{Se}$ & 431.7 & 603.9 & 118.6 & 77.07 & $2800^{\mathrm{c}}$ \\
$\mathrm{Zn}$ & & & & & $400^{\mathrm{b}}$ \\
& & & & & $200^{\mathrm{a}}$ \\
$\mathrm{Si}$ & 295.86 & 309.86 & 287.22 & 50.8 & - \\
$\mathrm{B}$ & 20.527 & 18.01 & 23.807 & 22.07 & - \\
$\mathrm{Ba}$ & 35.11 & 36.52 & 35.28 & 8.61 & - \\
\hline
\end{tabular}

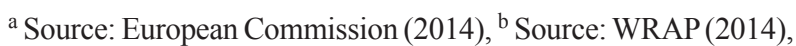

c Source: US Composting Council (TMECC 2010). SMD: Significance minimal difference $(\mathrm{P} \leq 0.05), \mathrm{CM}$ : cow manure, $\mathrm{WH}$ : water hyacinth, $\mathrm{WH}+\mathrm{CM}$ : water hyacinth plus cow manure

evaluate metals in compost because of the risks to the environment when using organic amendments with a high concentration of metals. Regulations about metals in compost exist in many countries except in México (Barrena et al. 2014, Mohee and Soobhany 2014).

The microbial quality of vermicompost is important because pathogens can cause damage to the health of those who handle this type of fertilizer. Microbiological results are shown in Table IV. Total and fecal coliforms and helminth eggs were present in low values in three vermicomposts $(0.55-0.62 \mathrm{he} / \mathrm{g})$. However, there are no regulations about the microbial content in compost. Results for $E$. coli were low in three vermicomposts and Salmonella was absent only in WH vermicompost according to the USEPA, European Commision, and WRAP regulations.

Hait and Tare (2011) found higher amounts of total and fecal coliforms, Salmonella and helminth eggs in vermicompost of sludge, in contrast with our low values. Interestingly, the British specification of quality compost for growth media requires the absence of such organisms (WRAP 2014). Care must be taken with handling vermicompost because it is not completely safe and can cause stomach diseases in susceptible individuals. Therefore, it is important to use proper management techniques with appropriate personal equipment.

\section{CONCLUSION}

Water bodies with WH problems can be managed by using the $\mathrm{WH}$ for vermicomposting, because it can produce a stable, mature and rich in nutrients vermicompost useful as organic fertilizer or soil improver. Besides, the whole process is carried out in a relatively short time: 110 days, including 20 days pre-composting and 90 days of vermicomposting. Vermicompost of WH has an important amount of metals and salts, however some seeds can thrive.

\section{ACKNOWLEDGMENTS}

We thank Blanca E. Manzo Cázares and M. Isabel Monares Escalera for their technical support. Lemon ranch (Secretaría de Desarrollo Rural-Michoacán) for providing the earthworms E. fetida and to Secretaría de Investigación y Posgrado del Instituto Politécnico Nacional for funding (SIP20140556).

TABLE IV. MICROBIAL PARAMETERS OF VERMICOMPOSTS

\begin{tabular}{lcccc}
\hline \multicolumn{1}{c}{ Microorganisms } & \multicolumn{4}{c}{ Vermicompost } \\
\cline { 2 - 5 } & $\mathrm{CM}$ & WH & WH+CM & Upper limit \\
\hline Escherichia coli $(\mathrm{CFU} / \mathrm{g})$ & $300 \mathrm{~b}$ & $110 \mathrm{a}$ & $420 \mathrm{~b}$ & $<1000^{\mathrm{abc}}$ \\
Salmonella spp. & $1 \mathrm{a}$ & $0 \mathrm{a}$ & $0.5 \mathrm{a}$ & $\mathrm{Absent}^{\mathrm{ab}}$ \\
(CFU/25g) & & & & $<3-300^{\mathrm{c}}$ \\
Total coliforms (CFU/g) & $150 \mathrm{a}$ & $100 \mathrm{a}$ & $150 \mathrm{a}$ & - \\
Fecal coliforms (CFU/g) & $90 \mathrm{a}$ & $60 \mathrm{~b}$ & $85 \mathrm{a}$ & $<1000-2 \times 10^{-6 \mathrm{c}}$ \\
Helminth eggs (he/g) & $0.55 \mathrm{a}$ & $0.5 \mathrm{a}$ & $0.62 \mathrm{a}$ & $<10-35^{\mathrm{c}}$ \\
\hline
\end{tabular}

${ }^{a}$ Source: European Commission (2014), ${ }^{\mathrm{b}}$ Source: WRAP (2014), ${ }^{\mathrm{c}}$ Source: US Composting Council (TMECC 2010). Rows with the same letter mean there are not significant differences $(\mathrm{P} \leq 0.05)$. CFU: colony forming units, he: number of helminths eggs, CM: cow manure, WH: water hyacinth, WH+CM: water hyacinth plus cow manure 
Dioselina Álvarez Bernal received a grant from Comisión de Operación y Fomento de Actividades Académicas del Instituto Politécnico Nacional.

\section{REFERENCES}

Allen H. P. (1990). Influence of cultivation system on earthworm populations. Agric. Engineers. 45, 26-27.

Alef K. and Nannipieri P. (1995). Methods in applied soil microbiology and biochemistry Academic Press. London, England, 576 pp.

APHA (1998). Standard methods for the examination of water and wastewater. 20a ed. American Public Health Association. Washington, USA, $1325 \mathrm{pp}$.

ASCP (2001). Quality criteria for composts and digestates from biodegradable waste management. Guidelines. Association of Swiss Compost Plants (ASCP) - Swiss Biogas Forum (Vol.11). Schoenbuehl, Switzerland, 12 pp.

Barrena R., Font X., Gabarrell X. and Sánchez A. (2014). Home composting versus industrial composting: influence of composting system on compost quality with focus on compost stability. Waste Manage. 34, 1109-1116.

DOI: 10.1016/j.wasman.2014.02.008

Bernal M. P., Paredes C., Sanchez-Monedero M. A. and Cegarra J. (1998). Maturity and stability parameters of composts prepared with a wide-range of organic wastes. Bioresour. Technol. 63, 91-99.

DOI: 10.1016/S0960-8524(97)00084-9

Bollo E. T. (1999). Lombricultura una alternativa de reciclaje. Soboc Grafic. Quito, Ecuador, 150 pp.

Bremner J. and Mulvaney C. (1982). Nitrogen total. Methods of soil analysis. Part 2. Chemical and microbiological properties Soil Sci. Soc. Am. Inc Publisher, Madison, Wisconsin, USA, 1159 pp.

Bustamante M., Paredes C., Marhuenda-Egea F., PérezEspinosa A., Bernal M. and Moral R. (2008). Cocomposting of distillery wastes with animal manures: Carbon and nitrogen transformations in the evaluation of compost stability. Chemosphere 72, 551-557.

DOI: 10.1016/j.chemosphere.2008.03.030

Cardoso L. and Ramírez E. (2001). Vermiestabilización de lodos residuales y lirio acuático. Proceedings. XXVII Congreso Interamericano de Engenharia Sanitária e Ambiental, ABES. Associacao Brasileira de Engenharia Sanitária e Ambiental, Sao Paulo, Brasil. 3-8 diciembre 2001.

Coetzee J. A., Byrne M. J. and Hill M. P. (2007). Impact of nutrients and herbivory by Eccritotarsus catarinensis on the biological control of water hyacinth, Eichhornia crassipes. Aquat. Bot. 86, 179-186.

DOI: $10.1016 /$ j.aquabot.2006.09.020
Ding J., Wang R., Fu W. and Zhang G. (2001). Water hyacinth in China: Its distribution, problems and control status. In: Biological and integrated control of water hyacinth, Eichhornia crassipes (M.H. Julien, Ed.). Second Meeting of the Global Working Group for the Biological and Integrated Control of Water Hyacinth, Eichhornia crassipes, Beijing, China, pp. 29-32.

Edwards C.A. and Bohlen P. J. (1996). Biology and ecology of earthworms. Chapman and Hall. London, England, 426 pp.

European Commission (2014). End of waste criteria for biodegradable waste subjected to biological treatment (compost and digestate): Technical proposals. Joint Research Center Scientific and policy reports. Final Report. European Commission. Sevilla, Spain, $312 \mathrm{pp}$.

Gajalakshmi S. and Abbasi S. A. (2004). Earthworms and vermicomposting. Indian J. Biotechnol. 3, 486-494.

Gajalakshmi S., Ramasamy E. V. and Abbasi S. A. (2001). Assessment of sustainable vermiconversion of water hyacinth at different reactor efficiencies employing Eudrilus engeniae Kinberg. Bioresour. Technol. 80, 131-135. DOI: 10.1016/S0960-8524(01)00077-3

Gupta R., Mutiyar P. K., Rawat N. K., Saini M. S. and Garg V.K. (2007). Development of a water hyacinth based vermireactor using an epigeic earthworm Eisenia foetida. Bioresour. Technol. 98, 2605-10. DOI: 10.1016/j.biortech.2006.09.007

Hait S. and Tare V. (2011). Vermistabilization of primary sewage sludge. Bioresour. Technol. 102, 2812-2820. DOI: 10.1016/j.biortech.2010.10.031

Hue N. V. and Liu J. (1995). Predicting compost stability. Compost Sci. Util. 3, 8-15. DOI: 10.1080/1065657X.1995.10701777

Iglesias-Jiménez E. and Pérez-García V. (1992). Determination of maturity índices for city refuse composts. Agric. Ecosyst. Environ. 38, 331-343.

INEGI (2015). Áreas geográficas. Instituto nacional de estadística geografía e informática. [Online] http:// www.beta.inegi.org.mx/app/areasgeograficas/?ag=16 20/07/2015.

Ingelmo F., Molina M. J., Desamparados-Soriano M., Gallardo A. and Lapeña L. (2012). Influence of organic matter transformations on the bioavailability of heavy metals in a sludge based compost. J. Environ. Manage. 95, S104-S109.

DOI: 10.1016/j.jenvman.2011.04.015

Khan N., Clark I., Sánchez-Monedero M. A., Shea S., Meier S. and Bolan N. (2014). Maturity indices in co-composting of chicken manure and sawdust with biochar. Bioresour. Technol. 168, 245-251.

DOI: 10.1016/j.biortech.2014.02.123 
Lasaridi K., Protopapa I., Kotsou M., Pilidis G., Manios T. and Kyriacou A. (2006). Quality assessment of composts in the Greek market: The need for standards and quality assurance. J. Environ. Manage. 80, 58-65. DOI: 10.1016/j.jenvman.2005.08.011

Malik A. (2007). Environmental challenge vis a vis opportunity: the case of water hyacinth. Environ. Int. 33, 122-38.

DOI: 10.1016/j.envint.2006.08.004

Mohee R. and Soobhany N. (2014). Comparison of heavy metals content in compost against vermicompost of organic solid waste: Past and present. Resour. Conserv. Recy. 92, 206-213.

DOI: 10.1016/j.resconrec.2014.07.004

Mupondi L. T., MnKeni P. N. S. and Muchaonyerwa P. (2011). Effects of a precomposting step on the vermicomposting of dairy manure-waste paper mixtures. Waste Manage. Res. 29, 219-228.

DOI: $10.1177 / 0734242 X 10363142$

Nelson D. and Sommers L. E. (1982). Total carbon, organic carbon, and organic matter. Methods of soil analysis. Part 2. Chemical and microbiological properties. Soil Sci. Soc. Am. Inc Publisher. Madison, Wisconsin, USA, 1159 pp.

Page A. (1982). Inorganic carbon. Methods of soil analysis. Part 2. Chemical and microbiological properties. Soil Sci. Soc. Am. Inc Publisher. Madison, Wisconsin, USA, 1159 pp.

Patil J. H., Sanil P. H., Malini B. M., Manoj V., Deepika D. and Chaitra D. (2012). Vermicomposting of water hyacinth with poultry litter using rotatory drum reactor. J. Chem. Pharm. Res. 4, 2585-2589.

Patidar A., Gupta R. and Tiwari A. (2013). Potential of microbial inoculated water hyacinth amended thermophilic composting and vermicomposting in biodegradation of agro-industrial waste. J. Bioremed. Biodeg. 4, 2-8

DOI: $10.4172 / 2155-6199.1000191$

PCIMALC (2005). Manifestación del impacto ambiental, modalidad regional para el proyecto: Programa de Control de Maleza Acuática del Lago de Chapala [Online]. http://sinat.semarnat.gob.mx/dgiraDocs/ documentos/jal/estudios/2005/14JA2005H0003.pdf $02 / 12 / 2014$.

Ruiz-Tellez T., Martín-de-Rodrigo-López E., LorenzoGranado G., Albano-Pérez E., Morán-López R. and Sánchez-Guzmán J. M. (2008). The water hyacinth, Eichhornia crassipes: an invasive plant in the Guadiana river basin (Spain). Aquat. Invasions 3, 42-53. DOI: 10.3391/ai.2008.3.1.8

Sánchez-Monedero M., Roig A., Paredes C. and Bernal M. (2001). Nitrogen transformation during organic waste composting by the Rutgers system and its effects on $\mathrm{pH}, \mathrm{EC}$ and maturity of the composting mixtures. Bioresour. Technol. 78, 301-308.

DOI: $10.1016 / \mathrm{S} 0960-8524(01) 00031-1$

Sánchez-Monedero M. A., Roig A., Martínez-Pardo C., Cegarra J. and Paredes C. (1996). A microanalysis method for determining total organic carbon in extracts of humic substances. Relationships between total organic carbon and oxidable carbon. Bioresour. Technol. 57, 291-295.

DOI: $10.1016 / \mathrm{S} 0960-8524(96) 00078-8$

SAS (2004). SAS Institute Inc. SAS/STAT® 9.1 User's Guide. Cary, NC. SAS Institute Inc. USA, 5136 pp.

Silva-García J.-T., Ochoa-Estrada S. and Estrada-Godoy F. (2006). Calidad química del agua subterránea de la Ciénega de Chapala como factor de degradación del suelo. Terra 24, 503-513.

Singh J. and Kalamdhad A. S. (2013). Effect of Eisenia fetida on speciation of heavy metals during vermicomposting of water hyacinth. Ecol. Eng. 60, 214-223. DOI: 10.1016/j.ecoleng.2013.07.010

TMECC (2010). The Test Method for the Examination of Composting and Compost. US Composting Council [Online]. http://compostingcouncil.org/tmecc/ 30/11/2014.

Uehara G. and Gillman G. (1981). The mineralogy, chemistry, and physics of tropical soils with variable charge clays. Westview Press, Boulder, USA, 170 pp.

USEPA(1995). EPA/B32-B-93-005. A guide to the biosolids risk assessment for the EPA Part 503 Rule. United States Environmental Protection Agency. Office of Wastewater Management, Washington, USA, 158 pp.

USEPA (1998). Method 1682: Salmonella spp. Environmental regulations and technology. In biosolids by enrichment, selection and biochemical characterization. United States Environmental Protection Agency. Office of Water, Washington, USA, $48 \mathrm{pp}$.

USEPA (2003). Appendix I. Control of pathogens and vector attraction in sewage sludge environmental regulations and technology. United States Environmental Protection Agency. Office of Research and Development. Cincinnati, USA, 183 pp. [Online] https://www. epa.gov/sites/production/files/2015-07/documents/ epa-625-r-92-013.pdf 14/10/2016

USEPA (2010). Method 1680: Fecal coliforms in sewage sludge (biosolids) by multiple tube fermentation using Lauryl Tryptose Broth (LTB) and EC Medium. Environmental regulations and technology. United States Environmental Protection Agency. Office of Water, Washington, USA, 50 pp.

WRAP (2014). Guidelines for the specification of quality compost for use in growing media. Waste and Resources Action Programme. [Online]. http://www. wrap.org.uk/sites/files/wrap/Growing_Media_Specification.pdf 5/12/2014. 
Zirbes L., Renard Q., Dufey J., Tu P. K., Duyet H. N., Lebailly P., Francis F. and Haubruge E. (2011). Valorisation of a water hyacinth in vermicomposting using an epigeic earthworm Perionyx excavatus in central Vietnam. Biotechnol. Agron. Soc. Environ. 15, 85-93.

Zhou W., Zhu D., Tan L., Liao S., Hu Z. and Hamilton D. (2007). Extraction and retrieval of potassium from water hyacinth (Eichhornia crassipes). Bioresour. Technol. 98, 226-231.

DOI: 10.1016/j.biortech.2005.11.011

Zucconi F., Pera A., Forte M. and Bertoldi M. (1981). Evaluating toxicity of immature compost. ByoCycle 22, 54-57. 